\title{
Serious gaming and mathematics. A perfect match. Over the reinforcement results of serious gaming and blended learning in mbo-education
}

\author{
Mr. H.G. de Zeeuw \\ ROC Kop van Noord-Holland
}

\begin{abstract}
How to cite this paper: H.G. de Zeeuw. (2019). Serious gaming and mathematics. A perfect match. Over the reinforcement results of serious gaming and blended learning in mboeducation. Journal of Applied Mathematics and Computation, 3(6), 640-643.
\end{abstract}

DOI: $10.26855 /$ jamc.2019.12.002

*Corresponding author: Dr. H.G. de Zeeuw, ROC Kop van Noord-Holland.

\begin{abstract}
Mathematics is one of the subjects many pupils in primary education struggle with. The PPON study for arithmetic/mathematics in primary education shows that the level at the end of grade 8 of the Dutch primary school did not, on average, improve between 1987 and 2004. [1] If the foundations laid in primary school is not adequate, it will have a lasting effect on the pupils' mathematical skills in secondary education and in the further education that is subsequently chosen. ROC kop van Noord-Holland is a follow-up course for MBO students, at levels 2.3, and 4, aged 16 to 23. It also offers adult education. At MBO 2 level, students regularly have a starting level at the end of primary school level. The starting level of the students at MBO 3 and 4 level shows a more diverse picture. In practice, there is a big difference between the students at the intake level. In order to motivate students for the mathematics course, to increase their math skills and to achieve a positive result for the exam, we have investigated whether blended learning and serious gaming can improve and secure the result during the course and during the exam. The research was done in consultation with Drs. W.F Kenter, training manager of ROC Kop van Noord-Holland. The results have led to a curriculum with different forms of education for the students, knowledge transfer to the teachers through which they have been informed about different forms of education and the entire department of 28 classes. The exam result is improved by 0.6 points.
\end{abstract}

\section{Keywords}

Math skills, adolescent, practical research, card games, digital game, teaching materials

\section{Blended learning: Serious Gaming in mbo mathematic education}

In addition to reading and writing, mathematics forms a basis for the rest of life. Regardless of which career choice or direction is chosen further in live, arithmetic will often be a part of daily activities. (Think weighing, measuring, budgeting etc.). We offer arithmetic education in a blended form. The moment we start the schoolyear is important. We always start testing our students at the start of the schoolyear/period with atest to determine a starting level. We do this to determine a starting level. We can also take an entry test for each separate discipline in the mathematic programme. Based on the results of the entry test, we prepare a training programme together with our students. [2] This plan covers the period from the first school week all the way to graduation and in this way, we guide the planning throughout the school period. [3] We make tailor-made solutions for our student and we customize our plans based on the individual skills and ambition. Of course, this programme is accessible on our intranet system to the student and the teachers that are involved. 
The power of the methodology, in addition to all the preconditions that we facilitate to create a good frame, stems from the use of different forms of education. After all, every student learns in his own way [4].

In addition to the theoretical teaching methods along with the accompanying teaching-and workbooks that we follow with the requirements set for our school, we use different teaching methods. To achieve this, we have developed various teaching materials. We work with a calculation card game. This is a game with 110 playing cards in which different game variations and with different difficulties are possible. Gaming is in line with the perception of the students. [5] We use a digital online calculation game in which the students learn, train and automate their basic maths skills (multiplying, addition and subtraction). This game is also used to understand sums in which "brackets" are used. We have consciously chosen to develop a game to connect with the experience of the students. A game is fun to play. It can be played at one's own level of education and thus a success experience is built up. This increases self-confidence. The challenge for the student to reach a higher level is not experienced as a learning process. In a playful way student train their skills, learn to think in solutions, reflect on their own actions, learn easily from others and are themselves challenged to help others.

The students have a 45-minute lesson, three times a week now. In lesson one we pay attention to theory in class. In the second and third lesson of the week the students work both individually and in groups with the card game and digitally with the online math game.

\section{Internal research at ROC Kop van Noord-Holland}

During the education program, students train in four blocks of ten weeks before an exam. The fifth block is a period in which exams are taken. In the sixth block the students can train on subjects for which they did not pass, and they can take the exam again.

To demonstrate that this way of receiving education yields better results for the students, we have formed three groups of like-minded people with the same educational background. In this case this means full primary education and four years of secondary education. At the time of our research, they had the same level of education. Fifty-three students are divided into three groups consisting of sixteen, seventeen and twenty students [6].

The first two groups received mathematic education in accordance with the basic methods: they received class instructions and used the lesson material from the textbooks and used a laptop when making the exercises from the textbooks. The third group has used the card game and the digital game.

The results after the first block of ten weeks immediately show a difference in the results of the two groups. The first two groups of sixteen and seventeen students respectively, who did not use the card and digital game, scored an average of 7.2 for group one and a 7.4 for group two. The third group of twenty people who did use the card and digital game, scored on average almost a whole point higher: an 8.2.

In blocks two and three, all three groups used the same tools. This means the regular methods supplemented with the card game and the digital game. The structure in the curriculum shows an aggravation for subjects that are experienced as more difficult. That average of groups one and two went up, despite a heavier program, namely a 7.3 for group one and a 7.6 for group two. The third group still scored the best with an average of 7.8 over a period of two periods of ten weeks.

With the presentation at the ALM London July 2018, we would start with block four after the summer holiday period and thus towards the exam period. The structure and build up towards the exams require more skills from all student. As the mathematics course does not count in receiving the diploma and completing the course, some students sometimes make the decision not to take the exam for our course and to give priority to courses that are important for obtaining the diploma. However, all students have decided to take the exam this time. [7] Group one closed the exam with an average grade of 6.4, group two with a 6.6 and group three with a 7.4.

The presence of the students in the lessons has increased measurably in all three groups. Also,the commitment during the lessons of the students is improved. They are much more active by playing the card game and the digital game. In addition, an average positive result was achieved with all three groups. In the end, 5 students from these three groups did not pass the exam in block five for different personal reasons. After extra training, again with all game forms, these students still succeeded in the last block. [8] This means that an upward trend in the result can be observed compared to previous years.

\section{Gaming as a tool to connect}

In addition to training on maths skills, this way of working has contributed in a different way to a better result for a specific group of students. These three classes consisted of student originating from war zones. They speak English at 
a basic level, but have different languages, cultures and religious backgrounds the group consisted of men and woman. The challenge was to turn these classes intro a group of people that would help and strengthen each other for at least the schoolyear and preferably for a longer period. In addition to working on math skills, social integration in Dutch society, speaking the English and Dutch language and long-term cooperation between students is an important part of the program.

In the first week we introduced the digital game to these three classes. And we also did a lot of calculation on the whiteboard to show that the way that they were probably trained in their old situation is a fine way to learn and work out math skills.

In the first month the group was divided into men and women. The groups played against each other in the digital game. Within their own groups, the male students and the female students started to help and encourage each other to achieve a better score. They did this at the individual level and therefore also at the group level.

After two months, the students asked each other for help and explanations to improve their math skills. This still happens within the created and separated groups of men and woman. They also explain to each other within their group what good tactics are to achieve better scores. The result of this is that several students managed to play within the top 100. The group with female students seemed keener on good results. They inquire about the results and really encourage each other specifically in this area.

After five months there is a different atmosphere within the classes. The male and female students approach each other to discuss math skills. Both in English and in Dutch. This improves speaking skills in both languages. Within the woman's group, the woman seemed less keen on the result and did not care about manifesting themselves within the top 100 of the game but instead remained focused on the solutions of the problems. Speed and total scores are less important to them Social interaction predominates. Within the men's group there are several students who have now gotten themselves inside the top 100 of the game, with higher scores than the woman initially had. Within this group, the experiences that are had and knowledge that are gained with other subjects and outside of school are also shared. In the lessons where the game is used, the students are focused on existing math skills and the new skills that are taught. There is a nice competition between the groups but also a real feeling of togetherness. The game makes it easy to discuss the solutions of the problems with each other and thus makes it easier to contact other people. This also trains language and communication skills. The final step is sharing experiences with each other regarding social integration within Dutch society. This development happened more and quicker in the woman's group then the men's group. After five months, men and woman from different cultural and religious backgrounds address each other more easily [9].

\section{Conclusion}

The regular learning method is supplemented by a game with playing cards and a digital game over a period of 5 times ten weeks. The use of different learning forms shows an average improvement in the learning outcomes of the three groups of students. A total of fifty-three students were followed for this study. Serious gaming and blended learning have increased the commitment and involvement of the students. The attendance of the students during the lessons has increased and the commitment during the lessons of the students has noticeably improved.

Connecting learning forms to the world of the students has made a positive contribution to this. The mathematics course is not a compulsory exam course, yet all students took the exam. The end results show an increase by ten percent compared to the previous three years.

The use of serious gaming speeds up and increases the interaction between the students during the lesson. This also happens in a group with people that differ from each other in cultural and religious background. When male and female students play the digital game within their own group, interaction is also developed here. Their speaking skills of the English and Dutch language has improved. And after a period of five months male and female students approach each other to discuss math skills.

\section{References}

[1] Programmeringsstudie/Rekenonderzoek in het primair onderwijs. Nederlandse Organisatie voor Wetenschappelijk Onderzoek. Den-Haag 27 oktober 2010 p.8-10

[2] P. Dawson, R. Guare, Executieve functies bij kinderen en adolescenten, Een praktische gids voor diagnostiek en interventie Februari 2019, Hogerefe Uitgevers bv Amsterdam Paperback 341 pagina's (ISBN: 9789079729005) 
[3] J. Jollens, Het tienerbrein. Over de adolescent tussen biologie en omgeving, (September 2017) Amsterdam University Press p.114-116 (ISBN: 9789462987470)

[4] D.A. Kolb, Experiential Learning: Experience as the Source of Learning and Development, (October 1983) FT Press Paperback, 288 pages (ISBN13: 9780132952613)

[5] Conferentie, Leer het brein kennen, Workshop 2. Cognitief versus sociaal leren in de adolescentie p.19 Nederlandse Organisatie voor Wetenschappelijk Onderzoek. 5 februari 2004

[6] Blended Learning: Praktijkonderzoek binnen de afdeling rekenonderwijs ROCKop van Noord-Holland: september 2017 tot december 2018

[7] Verslag paneldiscussie Rondom Rekenen. De toekomst van het rekenonderwijs;14 december 2016 Steunpunt Taal \& Rekenen vo. Steunpunt Taal \& Rekenen mbo. https://www.bvmbo.nl/2016 02 18/wp-content/ uploads/2017/02/20161214-Verslag-paneldiscussie-Rondom-Rekenen.pdf

[8] Blended Learning: Praktijkonderzoek binnen de afdeling rekenonderwijs ROCKop van Noord-Holland: september 2017 tot december 2018

[9] Blended Learning: Praktijkonderzoek binnen de afdeling rekenonderwijs ROCKop van Noord-Holland: september 2017 tot december 2018 